\title{
GAMBARAN BENDUNGAN ASI PADA IBU NIFAS DENGAN SEKSIO SESAREA BERDASARKAN KARAKTERISTIK DI RUMAH SAKIT SARININGSIH BANDUNG
}

\author{
${ }^{1}$ Clara Ega Ayu Rutiani, ${ }^{2}$ Lisna Anisa Fitriana \\ Prodi DIII Keperawatan FPOK Universitas Pendidikan Indonesia \\ Email: ${ }^{2}$ lisna@upi.edu
}

\begin{abstract}
ABSTRAK
Bendungan ASI merupakan salah satu masalah pada masa nifas. Bendungan ASI adalah penyempitan pada saluran ASI yang disebabkan karena air susu mengental sehingga menyumbat lumen saluran. Masa pemulihan pada ibu post seksio sesarea berangsur lebih lambat, beberapa hari setelah tindakan ibu masih merasakan nyeri. Kondisi tersebut menyebabkan ibu merasa cemas, bila ibu merasa tertekan (stress) maka akan terjadi pelepasan adrenalin yang menyebabkan vasokontriksi pembuluh darah pada alveoli. Akibatnya terjadi hambatan let-down reflex sehingga air susu tidak mengalir dan menalami bendungan ASI. Tujuan dari penelitian ini adalah untuk mengidentifikasi gambaran bendungan ASI pada ibu nifas dengan seksio sesarea di Rumah Sakit Sariningsih Bandung. Metode yang digunakan yaitu deskriptif kuantitatif, rancangan penelitian cross sectional, pengambilan sampel menggunakan accidental sampling. Jumlah sampel sebanyak 26 orang ibu nifas dengan seksio sesarea. Alat ukur penelitian ini menggunakan kuesioner six point engorgement scale (SPES). Hasil penelitian menunjukan 19 orang $(73,1 \%)$ ibu nifas terdapat bendungan ASI. Berdasarkan kelompok usia ibu nifas yang terdapat bendungan ASI terbanyak adalah kelompok usia 20-35 tahun sebanyak 18 orang $(69,2 \%)$. Berdasarkan kelompok pendidikan ibu nifas yang terdapat bendungan ASI terbanyak adalah kelompok pendidikan SMA yaitu sebesar 13 orang (50\%). Berdasarkan kelompok pekerjaan ibu nifas yang terdapat bendungan ASI terbanyak adalah kelompok ibu yang bekerja sebesar 10 orang $(38,5 \%)$. Berdasarkan kelompok paritas yang terdapat bendungan ASI terbanyak yaitu kelompok primipara sebanyak 11 orang (42,3\%). Dapat disimpulkan bahwa sebagian besar ibu nifas dengan seksio sesarea di Rumah Sakit Sariningsih Bandung terdapat bendungan ASI. Dengan hasil dari penelitian ini diharapkan dapat dilakukannya perawatan payudara dan penyuluhan mengenai bendungan ASI secara rutin di Rumah Sakit Sariningsih Bandung.
\end{abstract}

Kata kunci: Bendungan ASI, ibu nifas, seksio sesaria

\section{ABSTRACT}

Breast engorgement is one of a problem in postpartum period. A few days after getting the act of seksio caesarea, mother are usually pain and will being anxious. If mothers feel stress, there will be the release of the adrenaline causing vasoconstriction veins at alveoli and causing breast engorgement. The aim of this study is to identify the breast engorgement in mothers with seksio caesarea in Sariningsih Hospital in Bandung. The methods used the quantitative descriptive. The sample used accidental sampling. The number of samples are 26 people of mothers with seksio caesarea. The instrument used Six-point Engorgement Scale. The results showed that 19 people $(73,1 \%)$ mothers is breast engorgement. Based on age groups, mother with breast engorgement were age groups 20-35 year $(69,2 \%)$. Based on the education, the most were the group of education high school is as much as 13 people (50\%). Based on the capital work, the most were group of mothers who works as much as 10 people $(38,5 \%)$. Based on the parity that is most dam breastfeeding groups primipara about 11 people (42,3\%). We can conclude that the majority of mothers with seksio caesarea in Sariningsih Hospital are breast engorgement. With the result of research is expected did care breast and information about the breast engorgement routinely in Sariningsih hospital in Bandung.

Keywords: Breast engorgement, Mother parturition, \& Seksio caesarea 


\section{PENDAHULUAN}

Angka kejadian seksio sesarea di Indonesia menurut data survey nasional pada tahun 2007 adalah 921.000 dari 4.039.000 persalinan atau sekitar 22,8\% dari seluruh persalinan (Depkes RI, 2008). Seksio sesarea adalah suatu persalinan buatan dimana janin dilahirkan melalui suatu insisi pada dinding depan perut dan dinding rahim dengan syarat rahim dalam keadaan utuh serta berat janin diatas 500 gram (Jitowiyono, 2010).

Menurut Cunningham dkk (2009), masa nifas adalah suatu periode dalam minggu-minggu pertama setelah kelahiran. Lamanya "periode" ini tidak pasti sebagian besar menganggapnya antara 4 sampai 6 minggu. Walaupun merupakan masa yang relatif tidak kompleks dibandingkan dengan kehamilan, nifas ditandai oleh banyak perubahan fisiologis. Beberapa dari perubahan tersebut memungkinkan hanya sedikit mengganggu ibu baru, walaupun komplikasi serius juga dapat terjadi. Masalah yang terjadi selama masa nifas antara lain pendarahan persalinan, eklamsia, infeksi, bendungan asi (bengkak pada payudara atau breast engorgement), mastitis dan postpartum blues.

Salah satu masalah pada masa nifas adalah payudara bengkak atau bendungan ASI. Penyebab terjadinya bendungan ASI adalah ASI yang tidak segera dikeluarkan yang menyebabkan penyumbatan pada aliran vena dan limfe sehingga aliran susu menjadi terhambat dan tertekan ke saluran air susu ibu sehingga terjadinya peningkatan aliran vena dan limfe yang menyebabkan payudara bengkak. Hal ini di sebabkan karena perubahan proses fisiologis yang terjadi pada sistem endokrin karena hormon oksitosin yang di sekresikan ke kelenjar otak bagian belakang, yang bekerja pada otot uterus dan jaringan payudara. Pada tahap ketiga persalinan, hormon oksitosin berperan dalam pelepasan plasenta dan dapat merangsang produksi ASI, bila ASI tidak segera dikeluarkan maka akan terjadi bendungan ASI. Breast Engorgment (bendungan ASI) kebanyakan terjadi pada hari kedua sampai hari kesepuluh postpartum. Sebagian besar keluhan pasien adalah payudara bengkak, keras dan terasa panas (Sarwono, 2005).

Ibu yang melahirkan dengan tindakan seksio sesarea akan menghadapi masalah yang berbeda dengan ibu yang melahirkan secara normal. Pada ibu post seksio sesarea selain menghadapi masa nifas juga harus menjalani masa pemulihan akibat tindakan operasi. Masa pemulihan pun berangsur lebih lambat dibandingkan dengan yang melahirkan secara normal. Beberapa hari setelah tindakan seksio sesarea mungkin ibu masih merasakan nyeri akibat luka insisi, sehingga ibu akan merasakan kesulitan untuk merawat bayinya ataupun melaksanakan aktifitas sehari-harinya. Kondisi-kondisi tersebut menyebabkan ibu measa tidak berdaya dan cemas terhadap kesehatan dirinya dan bayinya (Danuatmadja \& Meilasari, 2007).

Kecemasan ini menyebabkan pikiran ibu terganggu dan ibu merasa tertekan (stress). Bila ibu mengalami stress maka akan terjadi pelepasan adrenalin yang menyebabkan vasokontriksi pembuluh darah pada alveoli. Akibatnya terjadi hambatan let-down refleks sehingga air 
susu tidak mengalir dan mengalami bendungan ASI (Soetjiningsih, 2005).

Menurut Wulandari dan Handayani (2011), bendungan ASI adalah suatu kejadian dimana aliran vena dan limfatik tersumbat, aliran susu menjadi terhambat dan tekanan pada saluran air susu ibu dan alveoli meningkat. Kejadian ini biasanya disebabkan karena air susu yang terkumpul tidak dikeluarkan sehingga menjadi sumbatan. Gejala yang sering muncul pada saat terjadi bendungan ASI antara lain payudara bengkak, payudara terasa panas dan keras dan suhu tubuh ibu sampai $38^{\circ} \mathrm{C}$. Apabila keadaan ini berlanjut maka dapat mengakibatkan terjadinya mastitis dan abses payudara. Bendungan ASI tersebut dapat dicegah dengan cara perawatan payudara yang dapat dilakukan oleh ibu. Selain perawatan payudara dapat mencegah terjadinya bendungan ASI, perawatan payudara juga dapat memperlancar proses laktasi.

RSU Tingkat IV Sariningsih Bandung adalah rumah sakit negeri kelas D yang mana hampir semua pasien di Rumah Sakit Sariningsih merupakan istri dari TNI. Menurut Kamilah (2011), dalam kehidupan seorang istri prajurit TNI, mereka akan dihadapkan dengan berbagai situasi di lingkungan masingmasing. Dibutuhkan kesiapan dalam mendukung dan setia mendampingi suami dimana pun mereka berada, tetapi beratnya tugas suami terkadang menjadi area yang mengeluh ASI tidak keluar, payudaranya mulai keras, mulai terdapat nyeri dan disertai dengan kenaikan suhu tubuh.

Berdasarkan latar belakang di atas penulis tertarik untuk melakukan penelitian dengan judul "Gambaran sebuah ancaman ketakutan bagi istri. Prajurit TNI pun seringkali mendapatkan tugas ke luar daerah tempat tinggal, sehingga mengharuskan untuk meninggalkan istri dan keluarga dalam waktu yang cukup lama. Kondisi seperti ini dapat menimbulkan kecemasan pada istri TNI tersebut. Kecemasan pada istri TNI juga dapat meningkat saat istri TNI sedang hamil dan akan melahirkan namun suaminya sedang ditugaskan keluar kota dan tidak bisa mendampinginya disaat melahirkan, karena dukungan suami juga sangat berpengaruh pada proses persalinan Hal ini bisa menyebabkan bendungan ASI.

Dari hasil penelitian sebelumnya Ratnasari, Wahyuni \& Hasifah (2014) di RSKDIA Siti Fatimah Makassar menunjukan dari 40 responden didapatkan hasil sebagian besar ibu nifas terdapat bendungan ASI sebanyak 28 orang (70\%). Sedangkan penelitian terjadinya bendungan ASI pada ibu nifas dengan seksio sesarea belum pernah dilakukan.

Berdasarkan data yang diperoleh hasil studi pendahuluan pada bulan April 2015 didapatkan data bahwa dari bulan Januari 2015 sampai dengan bulan Maret 2015 ada sebanyak $170 \mathrm{ibu}$ nifas dengan seksio sesarea yang di rawat di ruang nifas Rumah Sakit Sariningsih Bandung. Dari hasil observasi dan wawancara dengan ibu yang melahirkan dengan SC, ditemukan 3 ibu nifas dengan seksio ses Bendungan ASI pada Ibu Nifas dengan Seksio Sesarea di Rumah Sakit Sariningsih Bandung”.

\section{METODE}


Desain penelitian yang digunakan peneliti dalam penelitian ini adalah deskriptif dengan pendekataan kuantitatif dan rancangan penelitian cross sectional, dimana pengambilan data dilakukan secara potong lintang atau sekali datang dalam satu pertemuan. Pengambilan partisipan menggunakan accidental sampling, karena tidak dapat ditentukan berapa banyak jumlah responden. Subjek penelitian ini yaitu ibu nifas dengan seksio sesarea yang dirawat di Ruang Nifas Melati I Rumah Sakit Sariningsih Bandung sebanyak 26 partisipan yang diambil pada tanggal 29 Mei sampai 12 Juni 2015. Adapun kriteria Inklusi untuk responden pada penelitian ini yaitu ibu nifas pada hari ke-2 sampai hari ke-10, berusia lebih dari 17 tahun, dan kooperatif. Sedangkan kriteria eksklusinya yaitu memiliki komplikasi yang mempengaruhi proses laktasi, misalnya kanker payudara dan mengalami pendarahan yang menyebabkan kondisi nifas tidak stabil.

\section{HASIL}

Tabel 1 Distribusi Frekuensi Karakteristik Partisipan Penelitian Di Rumah Sakit Sariningsih

\begin{tabular}{lcc}
\hline Usia & f & $\mathbf{\%}$ \\
\hline$<20$ tahun & 0 & 0 \\
$20-35$ tahun & 25 & 96,2 \\
$>35$ tahun & 1 & 3,8 \\
\hline Pendidikan & $\mathbf{f}$ & $\mathbf{\%}$ \\
\hline SD & 0 & 0 \\
SMP & 0 & 0 \\
SMA/SMK & 15 & 57,7 \\
Perguruan Tinggi & 11 & 42,3 \\
\hline Pekerjaan & $\mathbf{f}$ & $\mathbf{\%}$ \\
\hline Bekerja & 15 & 57,7 \\
Tidak Bekerja & 11 & 42,3 \\
\hline Paritas & $\mathbf{f}$ & $\mathbf{\%}$ \\
\hline Primipara & 12 & 46,2 \\
Multipara & 14 & 53,8 \\
\hline $\mathbf{\Sigma}$ & 26 & 100 \\
\hline
\end{tabular}

\section{Karakteristik partisipan}

Berdasarkan tabel 1 dapat dilihat bahwa data dari 26 partisipan ibu nifas yang melahirkan di Rumah Sakit Sariningsih dengan seksio sesarea pada tahun 2015 hampir seluruh usia 20-35 tahun yaitu sebanyak 25 partisipan $(96,2 \%)$ dan sebagian kecil usia $>35$ tahun yaitu 1 partisipan (3,8\%). Berdasarkan pendidikan sebagian besar berpendidikan SMA/SMK yaitu sebanyak 15 partisipan $(57,7 \%)$ dan hampir setengahnya yaitu 11 partisipan $(42,3 \%)$ berpendidikan perguruan tinggi. Berdasarkan pekerjaan sebagian besar ibu bekerja yaitu 15 partisipan $(57,7 \%)$ dan hampir setengahnya ibu tidak bekerja yaitu 11 partisipan (42,3\%) . Berdasarkan paritas sebagian besar ibu multipara yaitu 14 partisipan $(53,8 \%)$ dan hampir setengahnya ibu primipara yaitu 12 partisipan $(46,2 \%)$.

\section{Gambaran Bendungan ASI Pada Ibu Nifas dengan Seksio Sesarea di Rumah Sakit Sariningsih Bandung}

\begin{tabular}{|c|c|c|}
\hline \multicolumn{3}{|c|}{$\begin{array}{l}\text { Tabel } 2 \text { Distribusi Frekuensi Partisipan } \\
\text { Berdasarkan Kejadian Bendungan ASI }\end{array}$} \\
\hline Bendungan ASI & $\mathbf{F}$ & $\%$ \\
\hline Terdapat Bendungan ASI & 19 & 73,1 \\
\hline $\begin{array}{l}\text { Tidak Terdapat Bendungan } \\
\text { ASI }\end{array}$ & 7 & 26,9 \\
\hline $\boldsymbol{\Sigma}$ & 26 & 100 \\
\hline
\end{tabular}

Berdasarkan tabel 2 data dari 26 partisipan ibu nifas dengan seksio sesarea yang melahirkan di Rumah Sakit Sariningsih Bandung menunjukan bahwa sebagian besar ibu nifas terdapat bendungan ASI yaitu 19 partisipan $(73,1 \%)$ dan hampir setengahnya tidak 
terdapat bendungan ASI yaitu 7 partisipan (26,9\%).

Tabel 3. Distribusi Frekuensi Pertisipan Bendungan ASI Berdasarkan Karakteristik Usia

\begin{tabular}{lcccccc}
\hline \multirow{2}{*}{$\begin{array}{c}\text { Bendungan } \\
\text { ASI }\end{array}$} & \multicolumn{6}{c}{ Usia } \\
\cline { 2 - 7 } & $\begin{array}{c}<\mathbf{2 0} \\
\text { tahun }\end{array}$ & \multicolumn{2}{c}{$\begin{array}{c}\mathbf{2 0 - 3 5} \\
\text { tahun }\end{array}$} & \multicolumn{2}{c}{$\begin{array}{c}\mathbf{. 3 5} \\
\text { tahun }\end{array}$} \\
\cline { 2 - 7 } & $\mathbf{f}$ & $\mathbf{\%}$ & $\mathbf{f}$ & $\mathbf{\%}$ & $\mathbf{f}$ & $\mathbf{\%}$ \\
\hline $\begin{array}{l}\text { Terdapat } \\
\text { Bendungan } \\
\text { ASI }\end{array}$ & 0 & 0 & 18 & 9,2 & 0 & 0 \\
\hline $\begin{array}{l}\text { Tidak } \\
\text { Terdapat }\end{array}$ & 0 & 0 & 7 & 26,9 & 0 & 0 \\
$\begin{array}{l}\text { Bendungan } \\
\text { ASI }\end{array}$ & & & & & & \\
\hline
\end{tabular}

Berdasarkan tabel nomor 3 dapat dilihat bahwa kejadian bendungan ASI berdasarkan usia ibu nifas di Rumah Sakit Sariningsih Bandung pada tahun 2015 ibu nifas dengan seksio sesarea yang terdapat bendungan ASI sebagian besar usia 20-35 tahun yaitu 18 partisipan $(69,2 \%)$ dan sebagian kecil ibu nifas usia $>35$ tahun yaitu 1 partisipan (3,9\%). Sedangkan ibu nifas dengan seksio sesarea yang tidak terdapat bendungan ASI hampir setengahnya usia 20-35 tahun yaitu 7 partisipan (26,9\%).

\section{Gambaran Bendungan ASI Pada Ibu Nifas dengan Seksio Sesarea Berdasarkan Karakteristik Pendidikan}

Tabel 4 Distribusi Frekuensi Partisipan Bendungan ASI Berdasarkan Pendidikan

\begin{tabular}{|c|c|c|c|c|c|c|c|c|}
\hline \multirow{3}{*}{$\begin{array}{c}\text { Bendunga } \\
\text { n ASI }\end{array}$} & \multicolumn{6}{|c|}{ Pendidikan } & & \\
\hline & \multicolumn{2}{|c|}{ SD } & \multicolumn{2}{|c|}{ SMP } & \multicolumn{2}{|c|}{$\begin{array}{l}\text { SMA/ } \\
\text { SMK }\end{array}$} & \multicolumn{2}{|c|}{$\begin{array}{l}\text { Pergurua } \\
\text { n Tinggi }\end{array}$} \\
\hline & f & $\%$ & f & $\%$ & $f$ & $\%$ & f & $\%$ \\
\hline $\begin{array}{l}\text { Terdapat } \\
\text { Bendungan } \\
\text { ASI }\end{array}$ & 0 & 0 & 0 & 0 & 13 & 50 & 6 & 23,1 \\
\hline $\begin{array}{l}\text { Tidak } \\
\text { Terdapat } \\
\text { Bendungan } \\
\text { ASI }\end{array}$ & 0 & 0 & 0 & 0 & 2 & 7,7 & 5 & 19,2 \\
\hline
\end{tabular}

Berdasarkan tabel 4 dapat dilihat bahwa kejadian bendungan ASI berdasarkan pendidikan ibu nifas di Rumah Sakit Sariningsih pada tahun 2015 ibu nifas dengan seksio sesarea yang terdapat bendungan ASI setengahnya pada pendidikan SMA/SMK yaitu 13 partisipan (50\%) dan sebagian kecil pada pendidikan Perguruan Tinggi yaitu 6 partisipan $(23,1 \%)$. Sedangkan ibu nifas dengan seksio sesarea yang tidak mengalami bendungan ASI sebagian kecil pada pendidikan perguruan tinggi yaitu 5 responden $(19,2 \%)$ dan hampir sebagian kecil pada pendidikan SMA/SMK yaitu 2 partisipan $(7,7 \%)$.

Gambaran Bendungan ASI Pada Ibu Nifas dengan Seksio Sesarea Berdasarkan Karakteristik Pekerjaan

\begin{tabular}{lcccc} 
Tabel 5 Distribusi Frekuensi Partisipan \\
Bendungan ASI Berdasarkan Pekerjaan \\
\hline
\end{tabular}

Berdasarkan tabel nomor 5 dapat dilihat bahwa kejadian bendungan ASI berdasarkan pekerjaan ibu nifas di Rumah Sakit Sariningsih Bandung pada tahun $2015 \mathrm{ibu}$ nifas dengan seksio sesarea yang terdapat bendungan ASI hampir setengahnya pada ibu nifas yang bekerja yaitu 10 partisipan $(38,5 \%)$ dan hampir setengahnya pada ibu nifas yang tidak bekerja yaitu 9 partisipan (34,6\%). Sedangkan yang ibu nifas dengan seksio sesarea yang tidak terdapat bendungan 
ASI sebagian kecil pada ibu nifas yang bekerja yaitu sebesar 5 partisipan $(19,2 \%)$ dan hampir setengahnya pada ibu nifas yang tidak bekerja yaitu 2 partisipan $(7,7 \%)$.

Gambaran Bendungan ASI Pada Ibu Nifas dengan Seksio Sesarea Berdasarkan Karakteristik Paritas

\begin{tabular}{|c|c|c|c|c|}
\hline \multicolumn{5}{|c|}{$\begin{array}{l}\text { Tabel } 6 \text { Distribusi Frekuensi Partisipan } \\
\text { Bendungan ASI Berdasarkan Paritas }\end{array}$} \\
\hline \multirow{3}{*}{ Bendungan ASI } & \multicolumn{4}{|c|}{ Paritas } \\
\hline & \multicolumn{2}{|c|}{ Primipara } & \multicolumn{2}{|c|}{ Multipara } \\
\hline & f & $\%$ & $\mathbf{f}$ & $\%$ \\
\hline $\begin{array}{l}\text { Terdapat Bendungan } \\
\text { ASI }\end{array}$ & 11 & 42,3 & 8 & 30,8 \\
\hline $\begin{array}{l}\text { Tidak Terdapat } \\
\text { Bendungan ASI }\end{array}$ & 1 & 3,8 & 6 & 23,1 \\
\hline
\end{tabular}

Berdasarkan tabel 6 dapat dilihat bahwa kejadian bendungan ASI berdasarkan paritas ibu nifas di Rumah Sakit Sariningsih Bandung pada tahun 2015 ibu nifas dengan seksio sesarea yang terdapat bendungan ASI hampir setengahnya pada ibu nifas dengan primipara yaitu 11 partisipan $(42,3 \%)$ dan hampir setengahnya pada ibu nifas dengan multipara yaitu 8 partisipan $(30,8 \%)$. Sedangkan yang ibu nifas dengan seksio sesarea yang tidak terdapat bendungan ASI sebagian kecil pada ibu nifas dengan multipara yaitu sebesar 6 partisipan $(23,1 \%)$ dan sebagian kecil pada ibu nifas dengan primipara yaitu 1 partisipan $(3,8 \%)$.

Bendungan ASI merupakan salah satu masalah pada masa nifas. Bendungan ASI yang disebabkan oleh penyumbatan pada saluran ASI dengan keluhan payudara keras, terasa sakit dan bisa juga disertai dengan kenaikan suhu tubuh. Hasil yang didapatkan dari penelitian ini yang dilakukan pada 26 partisipan terdapat sebagian besar 19 partisipan $(73,1 \%)$ ibu nifas dengan seksio sesarea di ruang nifas Rumah Sakit Sariningsih Bandung terdapat bendungan ASI, sedangkan hampir setengahnya atau sebanyak 7 partisipan (26,9\%) ibu nifas dengan seksio sesarea di ruang nifas Rumah Sakit Sariningsih Bandung tidak terdapat bendungan ASI. Jumlah kasus yang ditemukan di ruang nifas dengan Seksio Sesarea di Rumah Sakit Sariningsih Bandung hampir sama dengan hasil penelitian yang dilakukan di RSKDIA Siti Fatimah Makassar yang menunjukan responden yang terkena bendungan ASI sebanyak 28 partisipan (70\%) (Ratnasari, Wahyuni \& Hasifah, 2014). Hasil penelitian ini tidak sejalan dengan penelitian yang dilakukan di Puskesmas Tengaran Kecamatan Tengaran Kabupaten Semarang yang menunjukan dari 58 partisipan hanya sebesar 19 orang $(32,8 \%)$ ibu nifas yang terdapat bendungan ASI dan sebagian sebesar yaitu sebanyak 39 partisipan $(67,8 \%)$ ibu nifas yang tidak terdapat bendungan ASI (Aeni, Andayani dan Widodo, 2012). Hasil penelitian ini juga tidak sejalan dengan penelitian di Puskesmas Wuryantoro Wonogiri yang menunjukan dari 30 partisipan hanya sekitar 10 partisipan $(33,3 \%)$ ibu nifas yang terdapat bendungan ASI dan sebagian besar yaitu sebanyak 20 partisipan $(66,7 \%)$ ibu nifas tidak terdapat bendungan ASI.

\section{PEMBAHASAN}

Kejadian Bendungan ASI pada Ibu Nifas dengan Seksio Sesarea Berdasarkan Usia 
Hasil penelitian yang didapatkan berdasarkan usia sebagian besar ibu nifas dengan seksio sesarea yang terdapat bendungan ASI pada kelompok usia 2035 tahun yaitu sebanyak 18 partisipan $(69,2 \%)$ sementara untuk kelompok usia $>35$ tahun didapatkan sebagian kecil yaitu 1 partisipan $(3,9 \%)$ ibu nifas dengan seksio sesarea yang terdapat bendungan ASI.

Hal tersebut berbeda dengan penelitian Indriyani (2010), yang didapatkan data sebanyak 52,8\% ibu nifas dengan kelompok usia $>35$ tahun yang terdapat bendungan ASI, hal ini disebabkan karena usia $>35$ tahun merupakan usia yang beresiko untuk melahirkan sehingga akan meningkatkan kecemasan pada ibu nifas, yang mana kecemasan merupakan salah satu faktor yang bisa menyebabkan terjadinya bendungan ASI. Hal ini berbeda dengan penelitian Desmawati (2008) yang berpendapat bahwa usia tidak berpengaruh terhadap bendungan ASI karena yang lebih berpengaruh adalah tentang pengetahuan seseorang dalam melakukan pencegahannya supaya tidak terjadi bendungan ASI tersebut.

Hasil penelitian ini pun sesuai dengan pendapat Notoatmodjo (2010), yang menyatakan bahwa usia berpengaruh terhadap daya tangkap pola pikir seseorang, semakin bertambahnya usia seseorang maka akan berkembangnya pula daya tangkap dan daya pikirnya sehingga menyebabkan pengetahuan yang diperolehnya semakin membaik dan membuat seseorang dengan usia yang bertambah akan semakin waspada terhadap dirinya sendiri terutama tentang kesehatan dirinya sendiri.
Dari hasil penelitian yang didapatkan mengenai kejadian bendungan ASI pada ibu nifas dengan seksio sesarea berdasarkan usia, peneliti berasumsi bahwa usia ibu nifas berpengaruh terhadap terdapatnya bendungan ASI. Hal ini dibuktikan dengan banyaknya kejadian bendungan ASI pada kelompok usia 25-30 tahun kurangnya pengalaman, pemahaman tentang bendungan ASI dan informasi yang diketahui tentang bendungan ASI karena usia yang masih muda menyebabkan banyaknya kejadian bendungan ASI di Rumah Sakit Sariningsih Bandung.

\section{Kejadian Bendungan ASI pada Ibu Nifas dengan Seksio Sesarea Berdasarkan Pendidikan}

Hasil penelitian yang didapatkan berdasarkan pendidikan sebagian besar ibu nifas dengan seksio sesarea yang terdapat bendungan ASI pada kelompok pendidikan SMA/SMK yaitu sebanyak 13 partisipan (50\%) sementara dari kelompok pendidikan perguruan tinggi ditemukan sebanyak 6 partisipan $(23,1 \%)$ ibu nifas dengan seksio sesarea yang terdapat bendungan ASI.

Penelitian ini juga sejalan dengan penelitian Murniati, Suprapti \& Kusumawati (2012) didapatkan hasil sebagian besar ibu nifas yang mengalami bendungan ASI dengan pendidikan SMA sebanyak 17 partisipan (53,1\%). Untuk hasil penelitian Wulandari (2012) hampir setengahya $\mathrm{ibu}$ nifas dengan berpendidikan SMA/SMK sebanyak 16 partisipan (54\%) terdapat bendungan ASI dan menyatakan bahwa tingkat pendidikan seseorang berpengaruh terhadap terjadinya bendungan ASI. Hasil penelitian dari Hastuti (2013), juga 
menyatakan bahwa sebagian besar ibu nifas dengan pendidikan SMA terdapat bendungan ASI sebesar 55,9\%.

Hal ini sejalan dengan pendapat Notoatmodjo (2010), yang berpendapat bahwa tingkat pendidikan adalah upaya unuk memberikan pengetahuan sehingga terjadi perubahan perilaku positif yang meningkat serta pendidikan yang tinggi akan berpengaruh pada penerimaan halhal baru dan dapat menyesuaikan diri dengan hal baru tersebut, semakin tinggi tingkat pendidikan seseorang maka akan semakin mudah orang tersebut dalam menerima informasi sehingga semakin banyak pengetahuan yang dimiliki.

Dari hasil penelitian yang didapatkan mengenai kejadian bendungan ASI pada ibu nifas dengan seksio sesarea berdasarkan pendidikan, peneliti berasumsi bahwa tingginya tingkat pendidikan akan sangat berpengaruh terhadap kejadian bendungan ASI. Dibuktikan bahwa banyaknya kejadian bendungan ASI pada ibu nifas dengan seksio sesarea yang terdapat pada kelompok pendidikan SMA/SMK. Hal ini disebabkan karena seseorang dengan tingkat pendidikan yang tinggi akan lebih banyak mengetahui informasi, memiliki wawasan yang luas, serta daya tangkap dan pola pikir yang jauh lebih baik sehingga dapat mempunyai peluang untuk mengetahui informasi tentang bendungan ASI dan mengatasi bendungan ASI.

\section{Kejadian Bendungan ASI pada Ibu Nifas dengan Seksio Sesarea Berdasarkan Pekerjaan}

Hasil penelitian yang didapatkan berdasarkan kelompok pekerjaan hampir setengahnya ibu nifas dengan seksio sesarea yang terdapat bendungan ASI pada kelompok ibu yang bekerja yaitu sebanyak 10 partisipan $(38,5 \%)$ dan pada kelompok ibu yang tidak bekerja hampir setengahnya yaitu sebanyak 9 partisipan (34,6\%) ibu nifas dengan seksio sesarea yang terdapat bendungan ASI. Hal ini juga sejalan dengan penelitian Wulandari (2012), yang ditemukan bahwa sebagian besar ibu nifas yang bekerja yang mengalami bendungan ASI sebanyak 15 responden $(69,8 \%)$. Hasil penelitian ini sejalan data dari Depkes RI (2006), yang mengatakan bahwa terjadinya bendungan ASI di Indonesia terbanyak pada ibu-ibu yang bekerja sebanyak $36 \%$ karena kesibukannya dalam pekerjaan dan kesibukannya dalam rumah tangga. Hal ini pun sesuai dengan pendapat Brinch (2005), yang mengatakan bahwa dengan adanya kesibukan keluarga dalam pekerjaan menurunkan tingkat perawatan dan perhatian ibu dalam melakukan perawatan payudara sehingga akan cenderung mengakibatkan peningkatan angka kejadian bendungan ASI.

Dari hasil penelitian yang didapatkan mengenai kejadian bendungan ASI pada ibu nifas dengan seksio sesarea berdasarkan pekerjaan, peneliti berasumsi bahwa ibu nifas yang bekerja memiliki peluang yang lebih besar dalam terdapatnya bendungan ASI, hal ini disebabkan karena kurang tindakan untuk melakukan upaya pencegahan terhadap bendungan ASI seperti misalnya melakukan perawatan payudara dan jarangnya frekuensi menyusui bayinya dikarenakan oleh banyaknya aktivitas yang dilakukan oleh ibu yang bekerja dan kesibukan ibu dalam pekerjaan serta keluarga sehingga membuat ibu merasa lebih lelah dan menurunkan perhatian ibu 
terhadap dirinya sendiri, karena perawatan payudara dan frekuensi menyusui merupakan faktor terjadinya bendungan ASI. Hal ini dibuktikan dengan banyaknya ibu nifas yang bekerja yang terdapat bendungan ASI.

\section{Kejadian Bendungan ASI pada Ibu Nifas dengan Seksio Sesarea Berdasarkan Paritas}

Hasil penelitian yang didapatkan berdasarkan paritas sebagian besar ibu nifas dengan seksio sesarea yang terdapat bendungan ASI pada kelompok ibu dengan primipara yaitu sebanyak 11 partisipan (57,9\%). Hal ini tidak sejalan dengan penelitian Indriyani (2006), yang menyatatakan bahwa tidak adanya hubungan paritas dengan bendungan ASI pada ibu nifas. Hasil penelitian ini sejalan dengan penelitian Hastuti (2013), yang ditemukan sebanyak 20 partisipan $(58,3 \%)$ ibu nifas dengan multipara tidak terdapat bendungan ASI. Hal ini disebabkan karena jumlah anak yang dilahirkan dapat berpengaruh dengan pengalaman yang dimiliki ibu nifas, pengalaman akan mempengaruhi pengetahuan tentang bendungan ASI. Seperti pendapat yang dikemukan oleh Notoatmodjo (2010), sesuatu yang pernah dialami seseorang akan menambah pengetahuan tentang sesuatu yang bersifat informal, seseorang yang telah memiliki pengalaman sebelumnya maka pengetahuannya akan lebih baik, jadi pengalaman sseseorang dapat mencegah hal-hal yang tidak diinginkan terjadi.

Dari hasil penelitian yang didapatkan mengenai kejadian bendungan ASI pada ibu nifas dengan seksio sesarea berdasarkan paritas, peneliti berasumsi bahwa ibu nifas dengan paritas primipara akan memiliki peluang lebih besar dalam terdapatnya bendungan ASI, hal ini disebabkan karena ibu dengan paritas primipara belum pernah memiliki pengalaman sebelumnya tentang melahirkan, tentang menyusui bayinya, sehingga menyebabkan ibu tidak mengetahui bagaimana pencegahan bendungan ASI yaitu dengan cara sering menyusui bayinya. Jika ibu nifas dengan paritas primipara jarang menyusui bayinya maka akan terjadi pegumpulan air susu di dalam alveolus-alveolus kelenjar mammae dan akan menyebabkan terjadinya bendungan ASI. Kurangnya pengalaman tentang perawatan payudara juga dapat membuat ibu nifas dengan paritas primipara akan memiliki peluang lebih besar dalam terdapatnya bendungan ASI, karena frekuensi menyusui dan perawatan payudara merupakan salah satu faktor terjadinya bendungan ASI. Hal ini dibuktikan dengan banyaknya ibu nifas dengan paritas primipara yang terdapat bendungan ASI.

\section{SIMPULAN}

Berdasarkan data penelitian dapat disimpulkan bahwa kejadian bendungan ASI di Rumah Sakit Sariningsih Bandung bulan Juni 2015 menunjukan bahwa sebanyak 19 partisipan $(73,1 \%)$ terdapat bendungan ASI dan sebanyak 7 partisipan $(26,9 \%)$ tidak terdapat bendungan ASI. Dengan sebagian besar partisipan dari kelompok usia 20-35 tahun, kelompok pendidikan SMA/SMK, kelompok ibu yang bekerja dan kelompok paritas primipara. 


\section{DAFTAR PUSTAKA}

Arikunto, S. (2010). Prosedur Penelitian Suatu Pendekatan Praktek. Jakarta : Rineka Cipta.

Aeni, Andayani dan Widodo (2012). Hubungan Cara Menyusui Dengan Kejadian Bendungan ASI pada Ibu Nifas di Wilayah Kerja Puskesmas Tengaran Kecamatan Tengaran Kabupaten Semarang

Bahiyatun, (2009). Asuhan Kebidanan Nifas Normal. Jakarta : EGC

BKKBN, (2013). Profil Kependudukan dan Pembangunan Indonesia Tahun 2013. Jakarta: BKKBN.

Danuratmaja.B., Meiliasari.M. (2007). 40 Hari Pasca Persalinan, Masalah dan Solusinya. Jakarta: Puspa Swara

Depkes RI, (2006). Pedoman Umum Pemberian Makanan Pendamping ASI (MP-ASI) Lokal, Jakarta: Depkes RI.

Depkes RI, (2008). Profil Kesehatan 2007, Jakarta: Depkes RI.

Dinkes Surakarta, (2009). Angka Kematian Bayi dan Penyebab Angka Kematian Bayi di Surakarta Tahun 2009. Dinkes Surakarta.

Hidayat. (2007). Metode Penelitian Kebidanan dan Analisis Data. Jakarta :Salemba Medika.

Jitowiyono dan kristiyanasari. (2010). Asuhan Keperawatan Post Operasi. Yogyakarta : Nuha Medika.

Murniati, Suprapti \& Kusumawati. (2012). Hubungan Pengetahuan Ibu Nifas Tentang Bendungan ASI dengan Praktik Pencegahan Bendungan ASI (Breast Care) di Rumah Bersalin Nur Hikmah Kwaron Gubug.

Notoadmodjo, S. (2010). Ilmu Kesehatan Masyarakat. Jakarta : Rineka Cipta.

Notoatmodjo, S. (2010). Metode Penelitian Kesehatan. Jakarta : Rineka Cipta.
Nugroho. (2011). ASI dan Tumor Payudara. Yogyakarta : Nusa Medika.

Nurliawati, E. (2010). Faktor-Faktor yang Berhubungan dengan Produksi Air Susu Ibu Pasca Seksio Sesarea di Wilayah Kota dan Kabupaten Tasikmalaya. Thesis.

Ratnasari, Wahyuni \& Hasifah. (2014). Faktor-Faktor yang Mempengaruhi Terjadinya Bendungan ASI pada Ibu Post Partum di RSKDIA Siti Fatimah Makasar. Volume 4 nomor 3. 12 April 2015

Rukiyah, A. Y., Yulianti, L. (2010). Asuhan Kebidanan IV (patologi). Jakarta: CV Trans Info Medika

Sarwono. (2005). Ilmu Kebidanan. Jakarta: Yayasan Bina Pustaka Sarwono Prawirohardjo

Soetjiningsih. (2005). ASI, Petunjuk Untuk Tenaga Kesehatan, Jakarta: EGC

Sugiyono, (2010). Metode Penelitian Pendidikan. Bandung: Alfabeta.

Suherni, dkk. (2009). Perawatan Masa Nifas. Edisi 3. Yogyakarta: Fitramaya.

Sulistyawati, A. (2009). Buku Ajar Asuhan Kebidanan Ibu Nifas. Yogyakarta: CV Andi Offset.

Wulandari, S. R, Handayani, S. (2011). Asuhan kebidanan ibu masa nifas. Yogyakarta : Gosyen Publising

Wulandari, E. (2012). Gambaran Bendungan ASI di Rumah Bersalin An Nuur Sumber Surakarta. Volume 2 Nomor 5. Diperoleh 11 April 2015

Yulianti, Astuti \& Wahyuni. (2009). Pengaruh Pemberian Tersruktur Tentang Engorgement pada Masa Nifas Terhadap Pengetahuan Ibu Tentang Engorgement di BPS RIS Setyowati Desa Cepirin Kabupaten Kendal. Volume 3 Nomor 2. Diperoleh 3 Maret 2015 